Vol. 06, No. 04; 2021

ISSN: $2456-8643$

\title{
CROP PROTECTION INTERVENTIONS AND WILDLIFE DAMAGE MANAGEMENT AROUND KIBALE NATIONAL PARK, UGANDA
}

\author{
${ }^{1,2}$ Aggrey Rwetsiba and *Taddeo Rusoke ${ }^{1}$ \\ ${ }^{1}$ Nkumba University, School of Sciences, Entebbe 237, Uganda \\ ${ }^{2}$ Uganda Wildlife Authority, Monitoring and Research Unit \\ https://doi.org/10.35410/IJAEB.2021.5653
}

\begin{abstract}
Crop damage by wild animals affects farmers livelihoods (Rusoke, 2021). This paper presents data on crop protection interventions against wildlife damage on crops around Kibale National Park (KNP), western Uganda. Through purposive sampling 375 crop farmers bordering KNP owning gardens within 1-kilometer distance from the park boundary were selected to participate in the study by answering a household questionnaire on crop protection interventions against wildlife damage. Results reveal that farmers around KNP were involved in protecting their crops against wildlife damage through guarding (63\%), chasing wild animals from their gardens (12\%), drumming (9\%), lighting fire at night to scare away elephants $(6 \%)$, and growing buffer crops such as tea (3\%). Digging trenches, planting Mauritius thorns, setting up beehive fences and elephant deterrent boards were the major protected-area initiated crop protection interventions against wild animal crop damage around KNP. KNP management had dug trenches of up to $84 \mathrm{~km}$ mainly to deter elephant crop depredation. A total of 1,214 beehives were distributed to farmers in eleven sub-counties where crop damage was most reported. The beehives are set up in a line fences along the park boundary to stop elephants from crossing. Farmers in parishes where beehives were set up in form of fence lines and fully colonized reported less damage on their crops by elephants and increasing damage were reported in areas where beehive along the beehive fence lines was not colonized or broken down by poachers. Routine maintenance of trenches was reported to reduce rates of incidences of wild animals crossing the park boundary and attack crops in the gardens. Expanding trench networks and supplying more beehives to create beehive fence lines is recommended as effective measures to deter farmers' crops damage by certain wildlife species around Kibale National Park.
\end{abstract}

Keywords: Crop protection interventions, wildlife damage management, Kibale National Park.

\section{INTRODUCTION}

Crop protection interventions against wildlife depredation such as planting buffer crops, digging trenches, and planting Mauritius thorn hedges aim to deter wild animals from damaging farmers' crop farms. Crop damage by wild animals is in form of grazing, trampling, gnawing, foraging, and uprooting crops (Rusoke, 2021). Crop protection interventions enhance the livelihoods of farmers bordering protected areas through increased yields and protect farm structures (Rusoke et al., 2020). Interventions to protect crop farms from damage by wildlife are initiated by communities and protected area managers. The absence of effective protection interventions 
Vol. 06, No. 04; 2021

ISSN: $2456-8643$

against wildlife damage on crops results in severe economic losses to farmers in proximity to protected areas in Uganda (Mackenzie et al., 2015; Hill 2017).

Studies conducted by Sudip and Siddhartha (2015), crop depredation by wildlife was a function of the distance of the farmland from the park, size of the crop-raiding animals, frequency of their attacks on the farmland, and the type of crops grown. Farmers protected their crops through biofencing and participating in the digging of trenches to stop elephants and wild pigs from entering their gardens (Sudip and Siddhartha, 2015). Farmers set up watchtowers to guard crops against primates (Mollel, 2017) and throw flaming sticks and make noise to chase animals from their gardens (Osei-Owusu, 2018). Whereas guarding with help from dogs and physical guarding is the most preferred method by farmers, it requires constant human presence (Hill, 2017). Farmers around Kibale National Park set up fires at night to protect their farms from elephant damage and chase wild animals from their crop farms by throwing stones and sticks (Mackenzie et al., 2015) throwing fire stashes at elephants (Shova, 2015), setting up watch-over towers (Shaurabh and Sindhu, 2017), poisoning (Tweheyo et al., 2012), planting scare-crows, smearing maize cobs with cow dung (Rebekah 2015), and snaring wildlife are the most global crop protection methods against wildlife damage which are initiated by farming communities (Rod and William 2016). Protected area management like farmers has also devised interventions such as setting up beehive fences, elephant deterrent boards, and digging up trenches.

Beehive fences have been promoted globally by protected areas managers as a non-lethal crop protection intervention against elephants, it is considered a lesser costly intervention and provides honey for those farmers while protecting elephants from crossing and damaging farmers' gardens (Rivu and Jayson, 2016). In their study of Human-elephant (HEC) conflict as a growing concern in today's crowded world, Rivu and Jayson (2016) initiated to check the effectiveness of beehive fence as an eco-friendly, low-cost biological fence against crop-raiding Asian elephants (Elephas maximus). Rivu and Jayson (2016) randomly blocked elephant pathways to Mayilumpara under Karulai forest range using twenty beehive boxes for nine months, fourteen encounters of beehive fences by elephants were recorded, of the fourteen recorded encounters, it is only on two occasions the elephant successfully entered into the crop field by breaking the beehive fence line. Such a result highlighted the efficacy of beehive fences which are effective in Uganda and across Africa. This paper highlights the several crop protection interventions around Kibale National Park (KNP) aimed at deterring wild animals from damaging crop farms.

\section{METHODS}

The study area was Kibale National Park (KNP), which is approximately $795 \mathrm{~km}^{2}$. KNP is located in western Uganda at 0 13'- 0 41' $\mathrm{N}$ and 30 19' - 30 32' E (Birungi, 2021). According to Mackenzie and Ahabyona (2012), Kibale National Park is a habitat for 13 species of primates. Of these thirteen primates, six are recorded as wildlife crop-damaging species (Naughton-Treves, 2017). Wildlife crop damage is common around the park (UWA, 2015). The park is predominantly surrounded by crop farmers whose crops are often destroyed by chimpanzees (Businge et al., 2019). The park experiences well-distributed rainfall that favours two cropgrowing seasons (Birungi, 2021) and this facilitates crop damage by wildlife (UWA, 2015). KNP 
is bordered by five districts including Kamwenge, Kyenjojo, Bunyangabu, Kasese, and Kabarole. These are the districts where respondents were selected.

Using purposive sampling a total of 375 crop farmers bordering KNP within a 1-kilometer distance from the Kibale National Park boundary were involved in the study. A total of 149 crop farmers who participated in the study were from four sub-counties of the Kabarole district (Ruteete 35, Busoro 39, Hakibaale 40, and Kiko 35). Kasese had a total of 75 crop farmers from two sub-counties (Kitswamba 36 and Karusandara 39) and Kamwenge districts had 73 crop farmers from two sub-counties (Busiriba 36 and Bigodi 37) who participated in the study Kyenjojo district had 40 farmers who were from Nyabuharwa sub-county and 38 crop farmers from Rwimi S/C in Bunyangabu district who participated in the study. Household questionnaires were researcher-administered to collect data on crop protection interventions and wildlife damage management among farmers bordering Kibale National Park in western Uganda. Quantitative data which was analyzed using SPSS is presented in form of charts, graphs, tables, whereas qualitative data is presented thematically according to interventions designed to deter crop-damaging species.

\section{FINDINGS}

\section{Crop protection interventions for wildife damage management around KNP}

The study established several crop protection interventions aimed at deterring crop-damaging wildlife species from damaging crops around Kibale National Park. These deterrent methods were both protected-area initiated and community-led. Interventions such as the setting of beehive fence lines, digging up trenches, planting Mauritius thorn (Caesalpinia decapetala) fences also known as bio-fences, to the construction of elephant deterrent boards and scareshooting of strayed wildlife back to the park by rangers from Uganda Wildlife Authority were initiatives of Uganda Wildlife Authority and implemented by Kibale National Park management guided by the Park Management Plan and problem animal data collected from parishes bordering the park. 

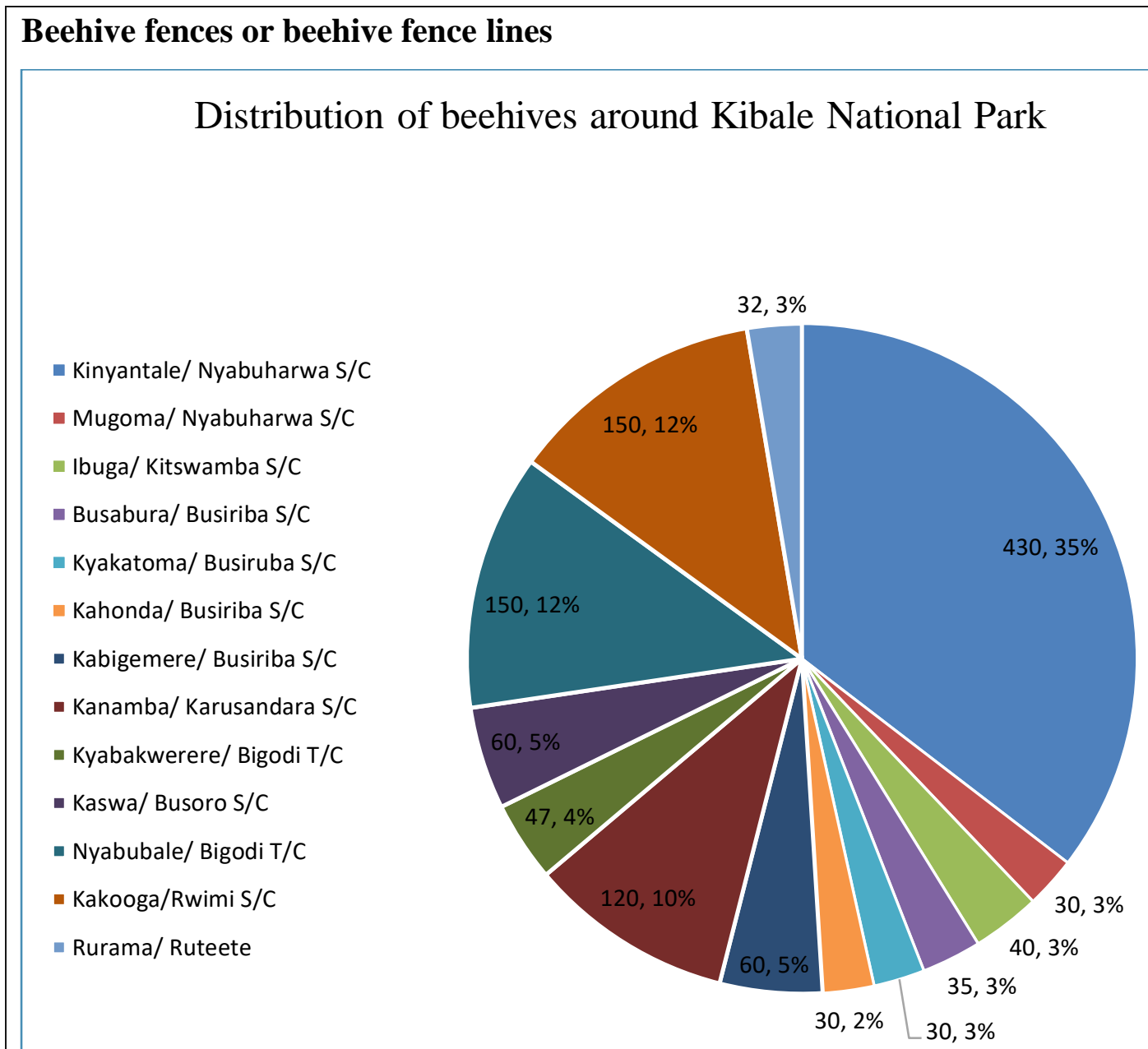

Figure 1: Distribution of beehives per parish around Kibale National Park 


\section{Adequacy of beehives/fences around KNP}

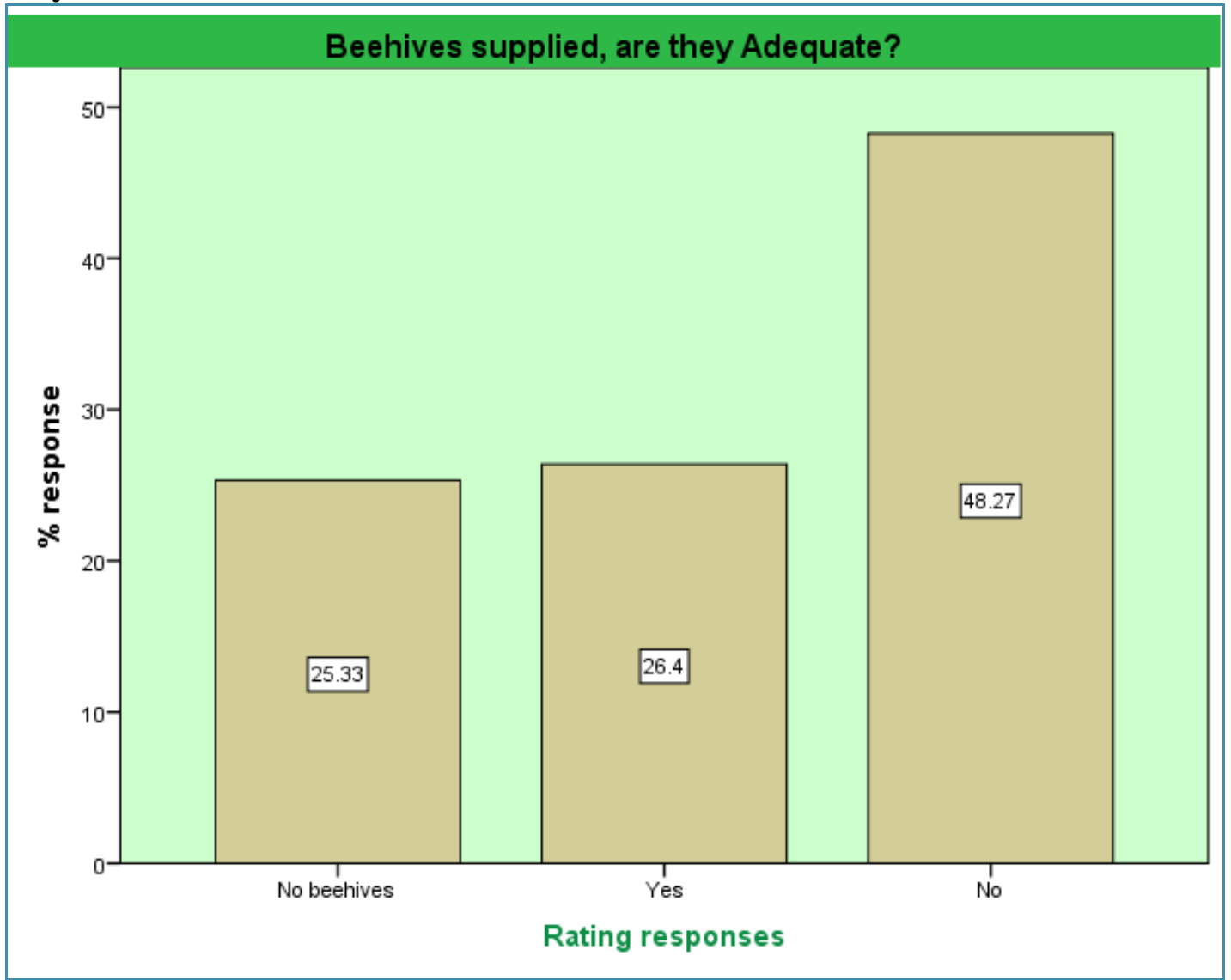

Figure 2: Adequacy of beehives supplied to farmers bordering Kibale National Park

Only $26 \%$ of the crop farmers agreed that the beehives were supplied to create beehive fences. This is a representation of about 1,214 beehives distributed around KNP, Figure 3 by the year 2020. All the beehives are used to construct beehive fences. Beehive fences are of double benefit to the communities around KNP. They stop elephants from crossing to gardens and farmers also get products such as honey and propolis. Of the eleven sub-counties surveyed, nine of them were supplied with beehives which are used to construct or set up beehive fence lines (see Plate 1) as interventions for problem animal management. There are no beehives supplied in Hakibaale SubCounty. 


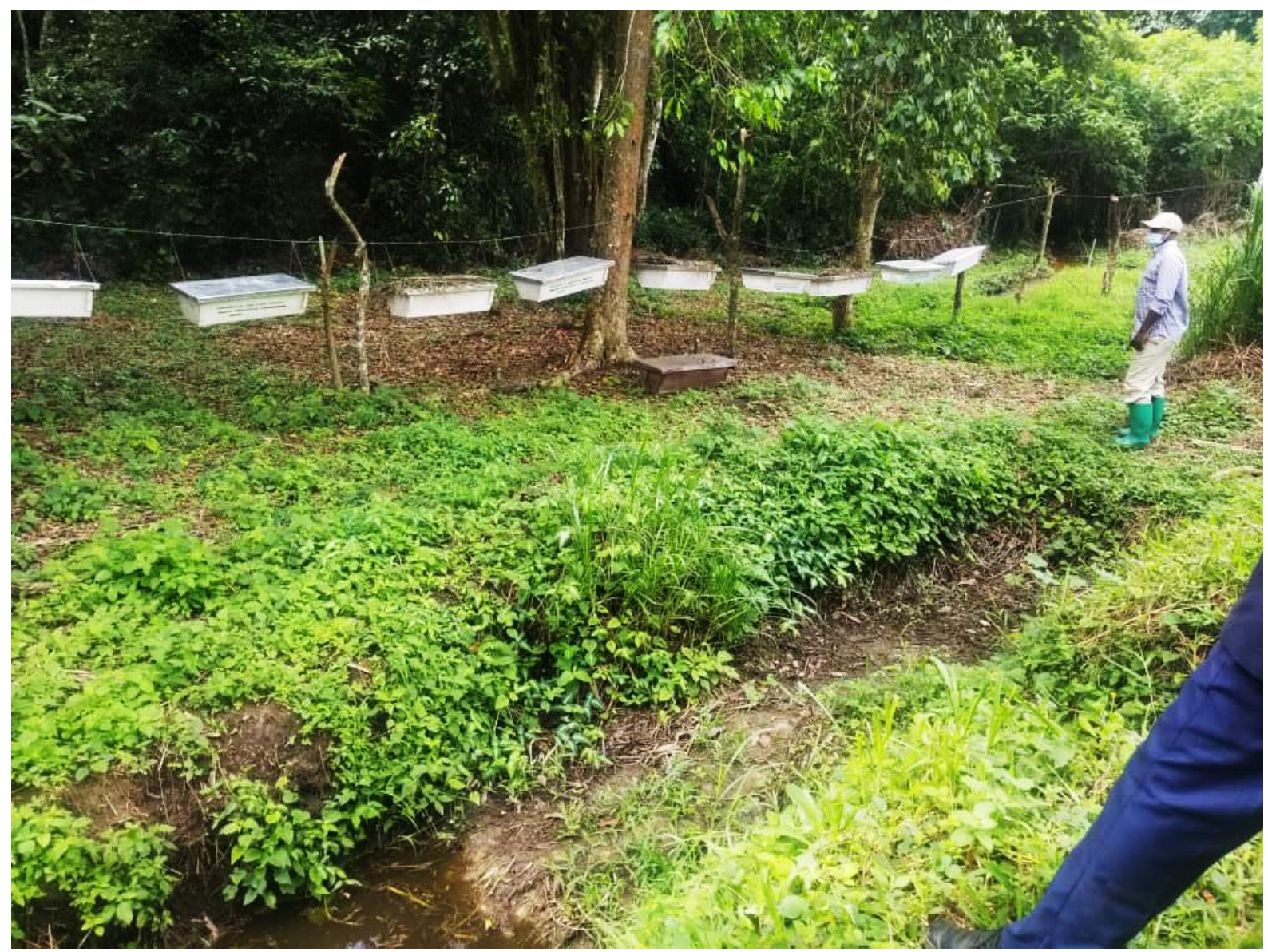

Plate 1: Beehives hanging on a wire to create a beehive-fence line in Kanimi Parish

\section{Planting of Mauritius thorns (Caesalpinia decapetala) as an intervention to deter crop} damage by wildlife

Scattered patches of untended Mauritius thorn plants were planted along the edges of the Mukole trench around Kibale National Park. The thorns are planted in form of hedges. Though these were not maintained, they covered an area of about five kilometers. According to reports from farmers and observations made, where Mauritius thorns were not well maintained, primates could find their way into crop farms.

From observations, Mauritius thorns were planted and well maintained in parishes such as Kahangi, Hakibaale sub-county in Kabarole district. Farmers from these parishes who were previously affected by wildlife damaging crops had gotten involved in maintaining Mauritius thorns. The Mauritius hedge fence is planted on the land that belongs to the park. The sections of well-maintained Mauritius thorn fence/hedge were reported to be effective in deterring wild animals such as baboons, vervet monkeys, and black \& white colobus monkeys (see Plate 2). Whereas Mauritius thorns fences were reported to be effective against deterring primates, most Mauritius thorn fences in Kiko Town Council were not maintained and Mauritius thorn plants were scattered growing at distant intervals. 


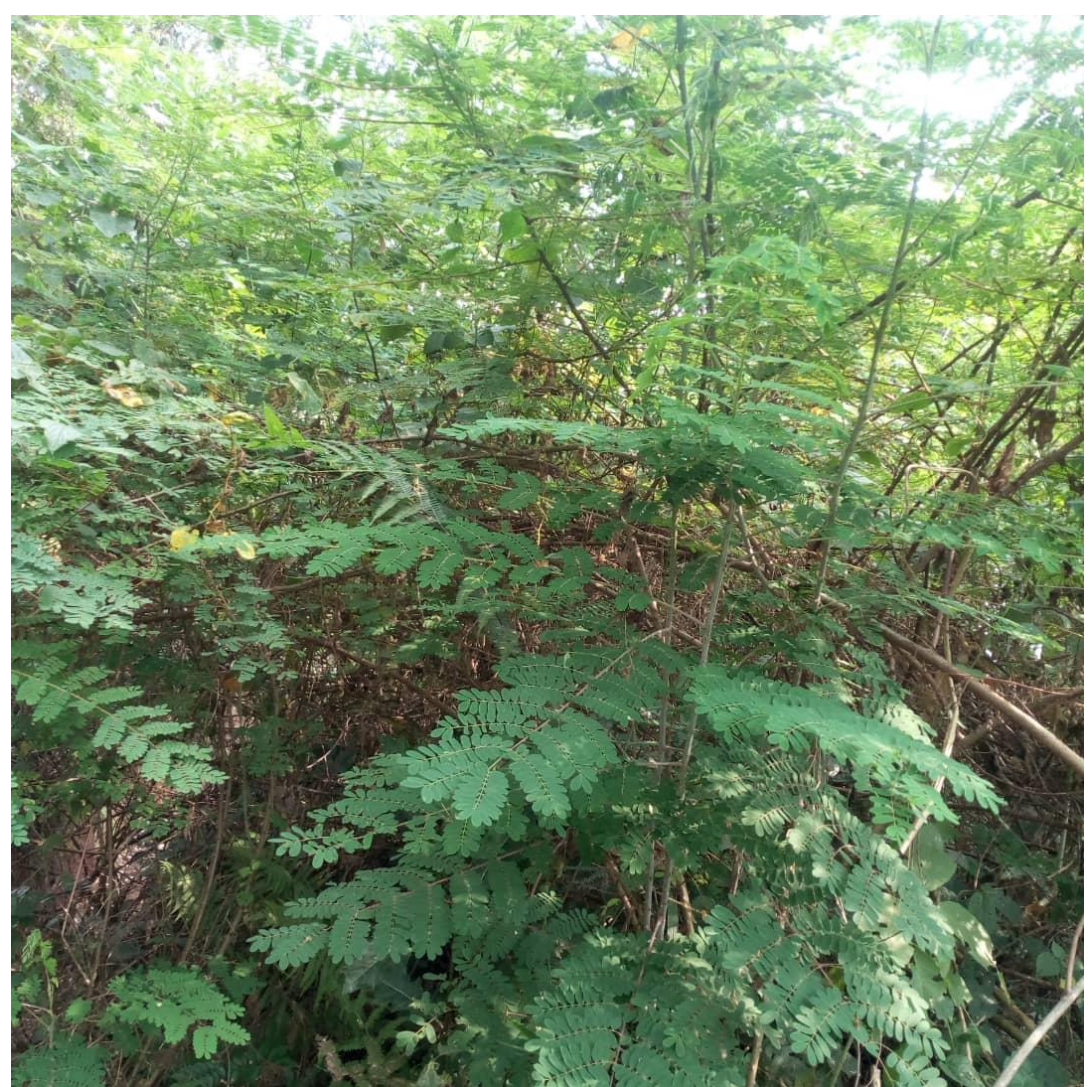

Plate 2: Mauritius thorn (Caesalpinia decapetala) hedge fence at the boundary of Kibale National Park Uganda.

\section{Digging of trenches as an intervention to deter crop damaging wildlife species}

A total trench network of about $84.5 \mathrm{kms}$ was dug around the boundary of Kibale National Park in 9 of the 11 sub-counties surveyed (Table 1). In comparison to the $220 \mathrm{~km}$, the total perimeter of KNP, about $38.4 \%$ of the park boundary is covered by trenches. Digging of a new trench costs 20,000 Uganda shillings per meter. Initially, trenches were dug at a width of $4 \mathrm{ft}$ by the depth of $5 \mathrm{ft}$. Trench maintenance is between 5,000 to 10,000 Uganda shillings per meter depending on the status of the trench. If the trench is not too filled up, trench maintenance workers charge KNP 10,000Uganda shillings, partly filled up 7,000 Uganda shillings, and when in the fair state, the charge is 5,000 Uganda shillings

Whereas we are supported by UWA, my active participation in the maintenance of the trench is to stop elephants from damaging my bananas, beans, and maize by elephants. when we maintain the trench, it's better than guarding our crops throughout the day and night. A respondent from Kanyante village. 
Table 1: Trench network, location and status around Kibale National Park

\begin{tabular}{|c|c|c|c|c|c|}
\hline \multicolumn{4}{|c|}{ Location of the trench network } & \multirow{2}{*}{$\begin{array}{l}\text { Length } \\
\text { (kms) }\end{array}$} & \multirow{2}{*}{$\begin{array}{l}\text { Status of the } \\
\text { trench }\end{array}$} \\
\hline District & Village & Parish & Sub-county & & \\
\hline \multirow[t]{5}{*}{ Kamwenge } & $\begin{array}{l}\text { Bujongobe, } \\
\text { Nkingo } \quad \& \\
\text { Nyabubale }\end{array}$ & Bujongobe & Bigodi TC & 9.3 & $\begin{array}{l}\text { Well } \\
\text { maintained }\end{array}$ \\
\hline & Kyabakwerere & Bigodi & Kamwenge & 2 & $\begin{array}{l}\text { Never } \\
\text { maintained } \\
\text { since } 2019\end{array}$ \\
\hline & $\begin{array}{l}\text { Ngenza } \quad \& \\
\text { Kiziba }\end{array}$ & Kahungye & Kamwenge & 6 & Not maintained \\
\hline & $\begin{array}{l}\text { Nyabitusi \& } \\
\text { Kyabandara }\end{array}$ & Kyabandara & Kamwenge & 10 & Not maintained \\
\hline & $\begin{array}{l}\text { Kabugemere } \\
\text { and Koburungi }\end{array}$ & Kanime & Busiriba & 6 & Not maintained \\
\hline \multirow[t]{9}{*}{ Kabarole } & Isunga & Isunga & Kasenda & 8.6 & $\begin{array}{l}\text { Well } \\
\text { maintained }\end{array}$ \\
\hline & Kanyante & Nyabweya & Kasenda & 4 & $\begin{array}{l}\text { Well } \\
\text { maintained }\end{array}$ \\
\hline & Nyabishenyi & Busoro & Busoro & 4 & Not maintained \\
\hline & Sebitoli A & Sebitoli & Busoro & 2 & Not maintained \\
\hline & Mugusu A-B & Busoro & Busoro & 3.2 & Not maintained \\
\hline & Kyansimbi & Kahangi & Hakibaale & 3 & Not maintained \\
\hline & Kyakabuzi & Rurama & Ruteete & 5.7 & Not maintained \\
\hline & Nyabubale Cell & Nyabubaale & Kiko & 3.5 & $\begin{array}{l}\text { Well } \\
\text { maintained }\end{array}$ \\
\hline & $\begin{array}{l}\text { Kanyawara } \\
\text { Ward }\end{array}$ & Kanyawara & Kiko & 2 & $\begin{array}{l}\text { Well } \\
\text { maintained }\end{array}$ \\
\hline Bunyangabu & Kakooga & Kakooga & $\begin{array}{l}\text { Kakinga } \\
\text { Rwimi S.C) }\end{array}$ & 1.5 & $\begin{array}{l}\text { Newly dug } \\
\text { trench \& well } \\
\text { maintained. }\end{array}$ \\
\hline Kasese & Ibuga & Hiima & Kitswamba & 3 & $\begin{array}{l}\text { Not maintained } \\
\text { (shallow \& } \\
\text { narrow) }\end{array}$ \\
\hline Kyenjojo & $\begin{array}{l}\text { Kamira and } \\
\text { Rwabaganda }\end{array}$ & $\begin{array}{l}\text { Kinyantale and } \\
\text { Rwabaganda }\end{array}$ & Nyabuharwa & 4.7 & Not maintained \\
\hline \multicolumn{4}{|l|}{ Total length } & $84.5 \pm 2$ & \\
\hline
\end{tabular}

Source: KNP-CCD and Field observation (2021). 


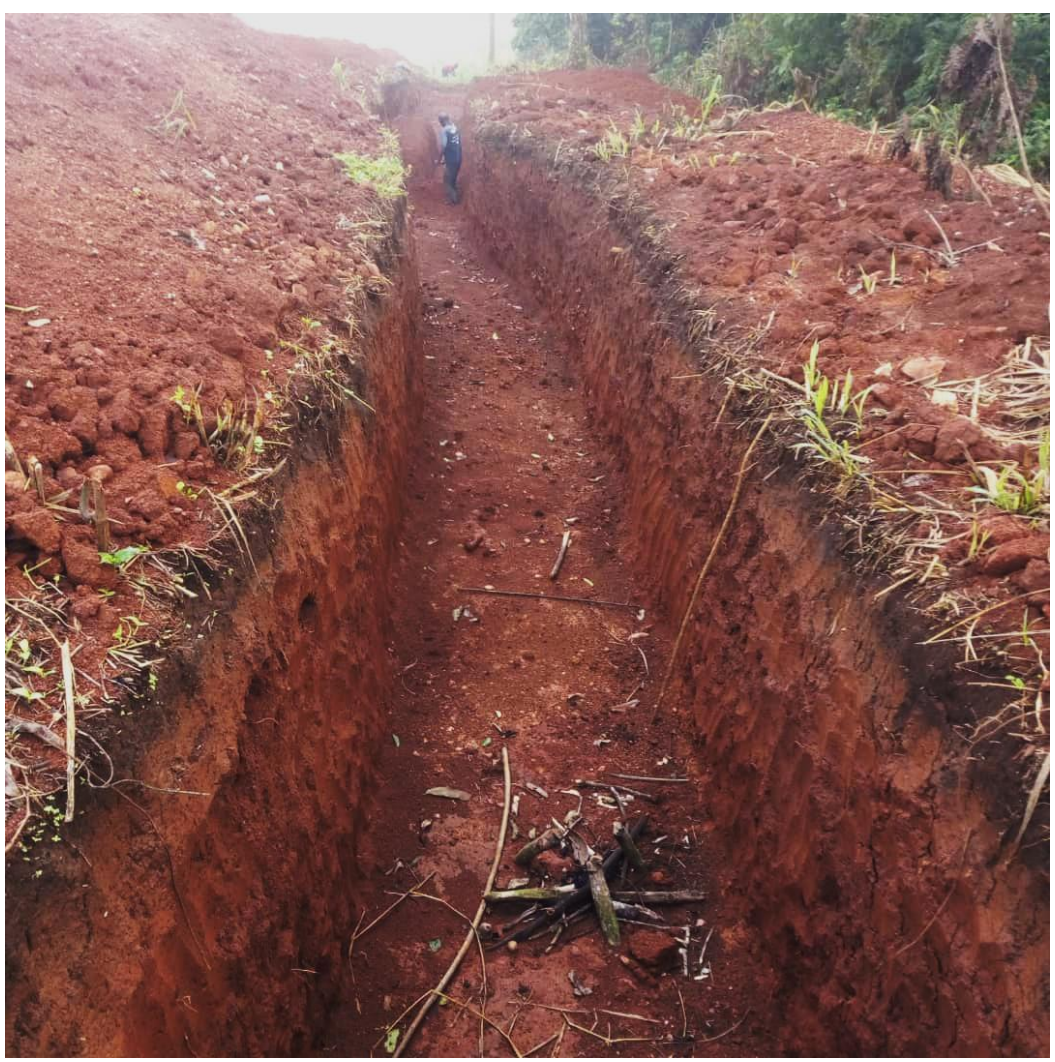

Plate 3: Trench dug in Kakooga Parish, Rwimi sub-county Bunyangabu district

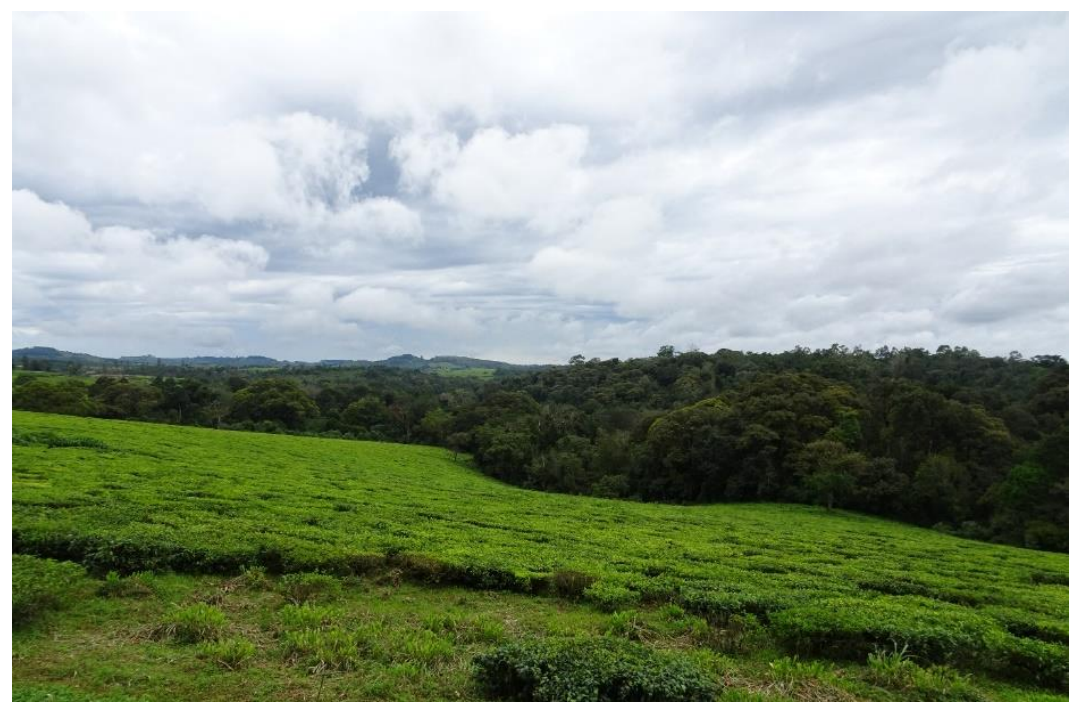

Plate 4: Tea plantation bordering Kibale National Park in Hiima Parish, Kyenjojo district Community-initiated crop protection interventions against wildlife damaging species 


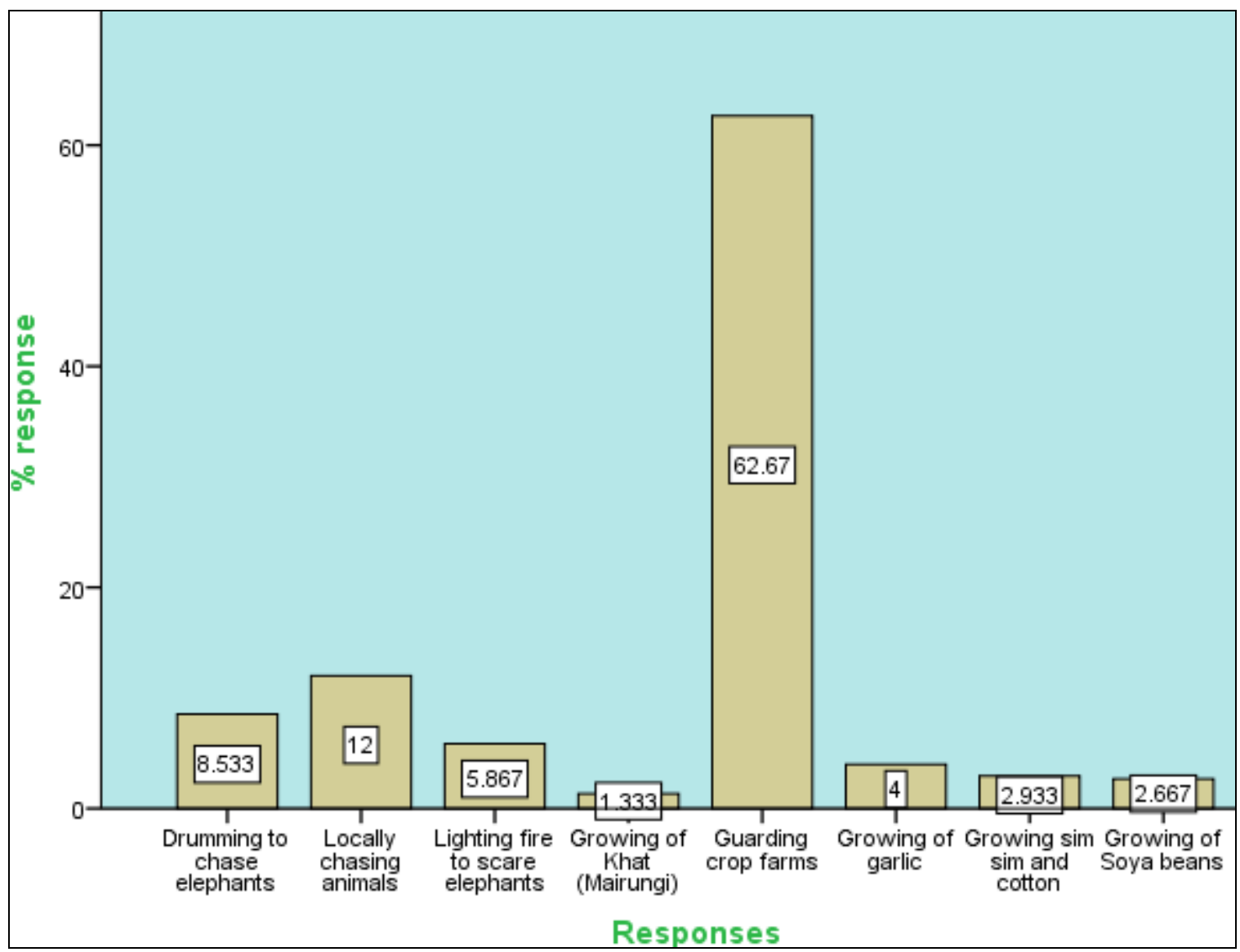

Figure 3: Community-initiated crop protection interventions for crop protection around KNP

\section{Planting of buffer crops as an intervention against crop damaging wildlife}

From observation made, some farmers in Kahangi village in Hakibaale sub-county planted Khat (Catha edulis) as a crop that was not damaged at all by wildlife (see Plate 5). The warden for community conservation, KNP also acknowledged that the number of farmers growing Khat was on the increase in Hakibaale sub-county. Some crop farmers had started growing other crops that are occasionally damaged by wildlife such as cowpeas growing in Nyabubale parish in Busiriba sub-county (see Plate 6). Other crops such as garlic, sim-sim, and cotton were also grown in Kitswamba sub-county in the Kasese district.

".... I continue growing buffer crops such as coffee because coffee is not wholly destroyed by wildlife, but due to infertile soil in Rurama, my coffee yields are low. However, Kibale National Park is supporting Rurama Women Handicraft and Farming Society, by allowing us to collect craft materials, and also providing us with transport on Women's Day $\left(08^{\text {th }}\right.$, March) to attend such occasions". A respondent from Rurama Parish, Ruteete S/C. 


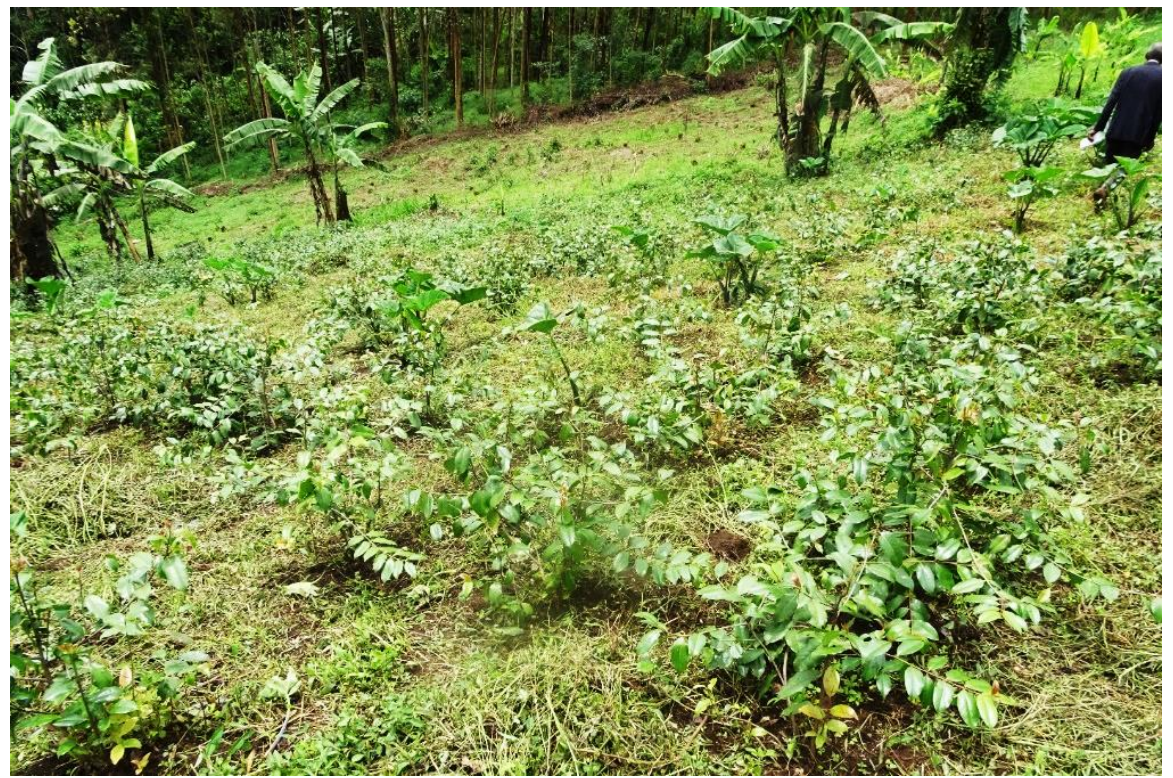

Plate 5: Khat plant (Catha edulis) planted as buffer crop in Kahangi village, Hakibaale Kabarole district.

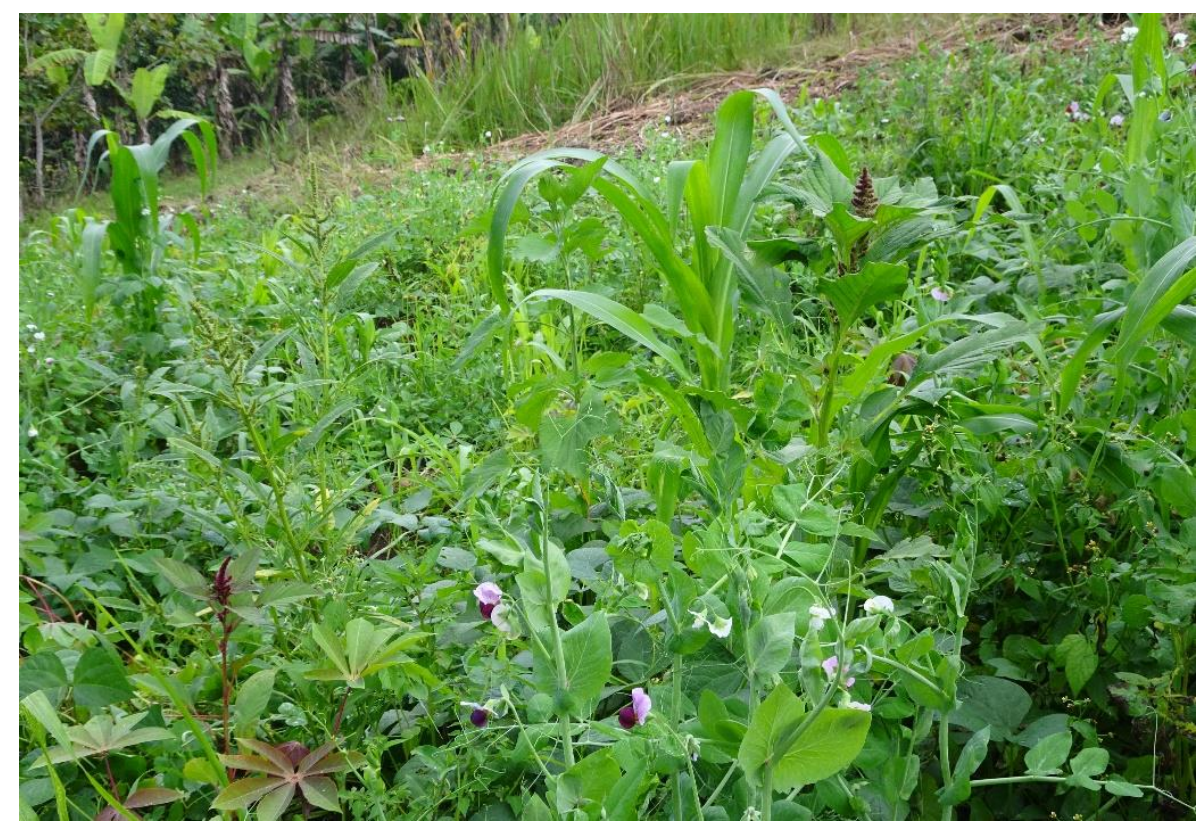

Plate 6: A garden of Cow peas interplanted with maize in Nyabubaale Parish, Kamwenge district.

Construction of shelters to guard fields from damage by wildlife.

Farmers bordering Kibale National Park construct shelters where they stay guarding fields against crop damage by wildlife. Constructed shelters were sighted in Ibuga parish and Busiriba sub-county in Kasese and Kamwenge districts. When farmers retire from guarding, sometimes their shelters were crushed by wildlife (see plate 7). 
Vol. 06, No. 04; 2021

ISSN: $2456-8643$

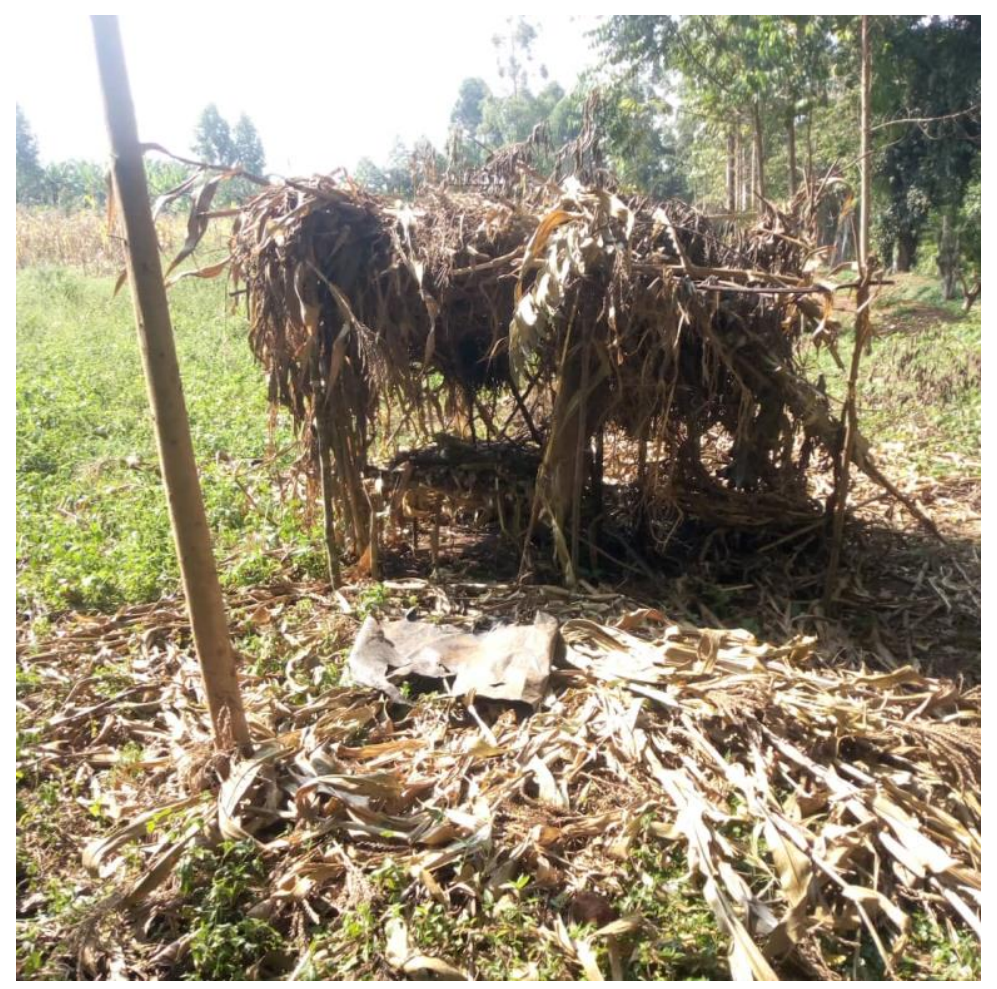

Plate 7: A crushed shelter that was used by people while guarding fields against elephants in Kibale National Park 


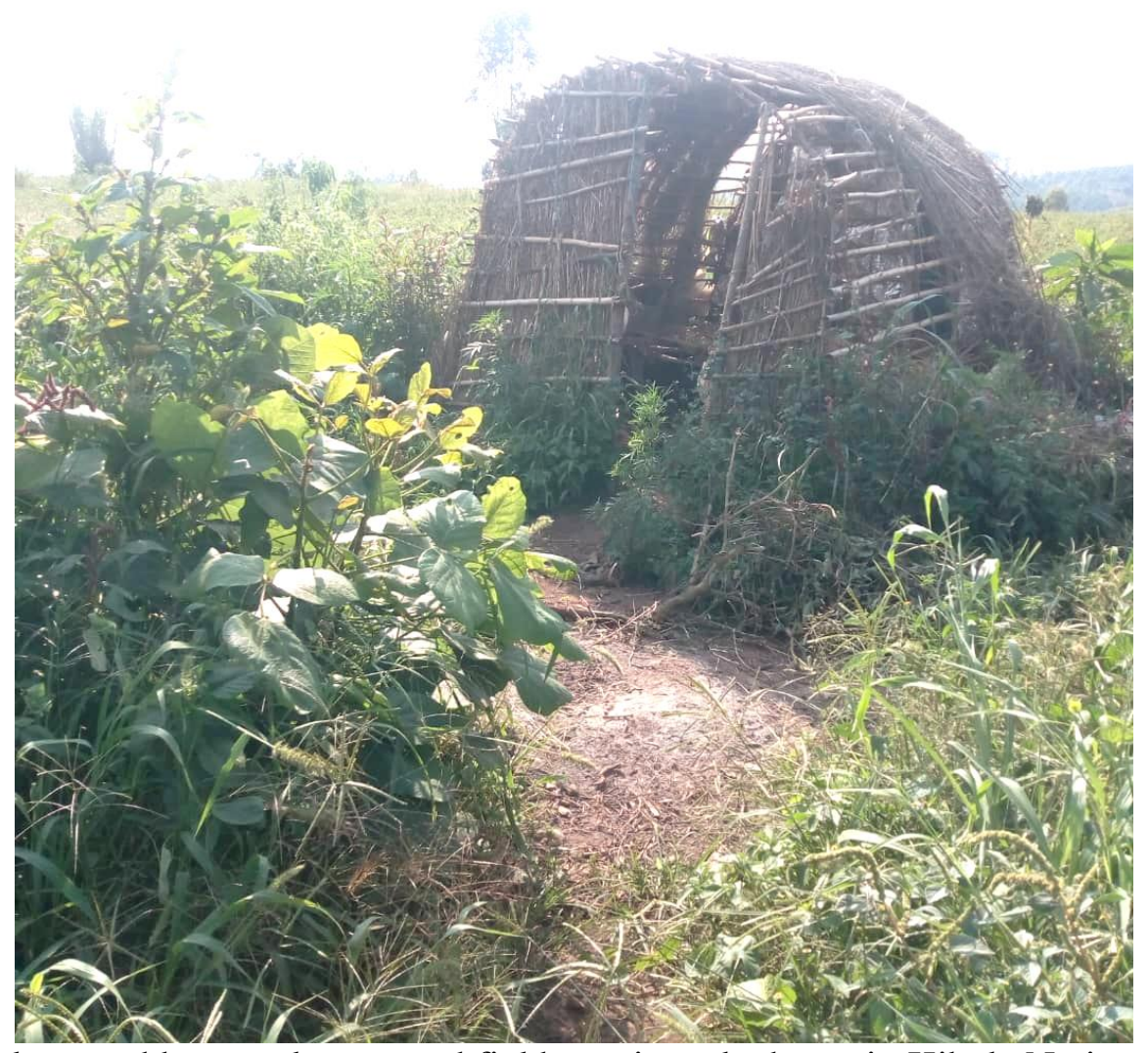

Plate 8: A shelter used by people to guard fields against elephants in Kibale National Park

Drumming and sounding tins to chase elephants from gardens as an intervention

In Kaswa Parish, Hakibaale sub-county, farmers revealed that they sound traditional drums, empty tins, and jerrycans to chase away crop-damaging wildlife such as elephants from gardens. Some $8.5 \%$ of the respondents practiced these interventions as shown under community-led initiatives in Figure 4.3

\section{Elephant deterrent boards}

Setting up of elephant deterrent board in Kanyawara and Kakooga villages in Kiko trading center and Kakooga parishes respectively. In total, UWA had set up only two (02) elephant deterrent boards. The deterrent board in Kanyawara parish is shown in Plate 9. 


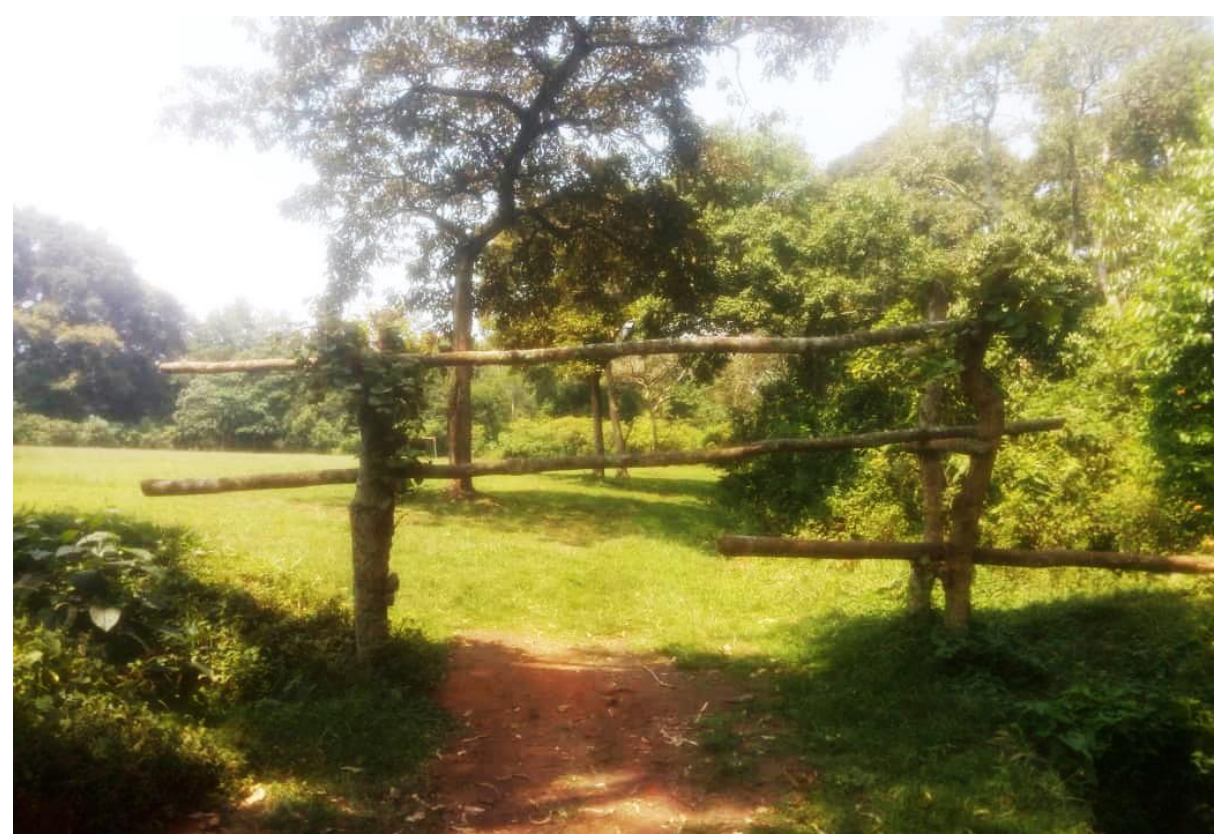

Plate 9: Elephant deterrent board in Kanyawara Parish, Kiko Town Council, Kabarole district

Guarding crop gardens with help from dogs as an intervention to deter wildlife from damaging crops

Crop farmers around KNP continued to guard crops against wildlife damaging species. This was the most practiced intervention at $62.67 \%$, Figure 3. Traditional guarding with help from dogs and physically guarding crops by throwing stones at monkeys and baboons are commonly practiced. Sometimes dogs are tied at the periphery of gardens or farmers build temporary structures where they guard their crops against. Guarding also involves locally cashing animals from gardens at $12 \%$ as shown in Figure 3. As observed in Sebitoli parish, farmers guard their gardens with help of dogs specially to deter crop destruction by baboons which were reported as the most crop-damaging wildlife species.

\section{Lighting fire to scare elephants from destroying crop gardens}

In Kiko trading center, respondents from Kanyansohera and Kasojo villages reported that to avoid elephant crop damage, they had complimented most of the traditional methods of crop protection by lighting fires at night to chase away elephants 5.8\%, Figure 3.

The study explored further the effectiveness of drumming, lighting fire, and chasing animals from the gardens. It was discovered that the three interventions were inefficient in deterring cropdamaging wildlife. As crop farmers lit fires to scare away elephants in Kiko and Kaswa parishes, respondents from Rwetera complain of Hippos from Nyabikere Crater lake in Rurama Parish which raid and damage maize and matooke gardens. Hippos are not deterred by lit fires.

\section{DISCUSSION \\ Beehive fences as an intervention to deter crop damaging wild animals}


Vol. 06, No. 04; 2021

ISSN: $2456-8643$

Farmers report that in areas where beehives have been colonized, elephants avoided crossing at such points. This evidence suggests that beehive fences significantly reduce crop losses from elephants. Apart from using beehives as an intervention to deter crop-damaging wildlife such as elephants, farmers gained income from the sale of honey and other bee products such as propolis. King et al., (2017) observed that elephants in the wild regularly avoid areas that are colonized by African honey bees (Apis mellifera scutellata), noting that elephants move away from bee sounds, make alarm calls to warn family members of potential threats posed by bees, and keep a safe distance of approximately $4 \mathrm{~m}$ from beehives (King et al., 2007). When the beehives are colonized and set along wires at a distance of six meters apart, they prove to be effective in deterring elephants from crossing to gardens to damage crops.

The effect of setting up beehive fence lines in Nyabishenyi village in the Busoro sub-county was reduced incidence rates of crop damage from elephants according to reports from farmers. In this village, a beehive fence line of 100 meters was well maintained. However, there were reports that subsistence poachers in Kinyantale parish would remove some uncolonized beehives from the wire in Kinyantale so that they can easily enter the protected area and poach wild animals.

In Sebitoli parish Busoro Kabarole district, 45 beehives were supplied by Kibale National Park management to members of Sebitoli Conservation Project. Of these beehives supplied, twentyfive had been colonized as of April 2020. A total of 180 beehives had also been supplied to other three (03) community conservation groups in Kinyantale and Rwabaganda parishes in Kyenjojo district. In Kyenjojo district, beehive fences were being used mostly as a major intervention to deter crop damage by wildlife. Kinyantale parish alone has a beehive fence line of about $200 \mathrm{~m}$. In Kinyantale parish since 2012, members of the Nature Conservation Community Project (NCP) have received 46 beehives, 34 beehives were also supplied to members of Kinyantale Wild Bee Keeping Project (KWBP) since 2017 and in the year 2019, group members of Kinyantale Community Beekeeping Project (KCBJ) had received 100 beehives to set up beehive fences.

In Kiko Town Council Kabarole district, three (03) community groups had received 530 beehives. The benefiting groups include Isule Trench maintenance and Conservation Group (ITCG) which received 150 beehives, Nyabinyungu Elephant Protection Group (NEPG) which received 300 beehives, and Kyamugarra Beekeeping Group (KBG) which received 80 beehives. The beehives are used to set up beehive fence lines. Generally, farmers reported that beehive fences were relatively effective in all areas where they were set up around the boundary of Kibale National Park. This finding relates to similar studies conducted in Kerala National Park in India by Riju and Jayson (2016) who discovered that elephants avoided areas with beehive fences. In their study Riju and Jayson established that out of 24 attempts made by elephants to cross the beehive fences, only four were successful. The four successful attempts were when the beehive fences were broken down by poachers. Unlike in Kerala National Park in India where beehives were placed on wires along poles, beehives around KNP are tied along with living trees as shown in Plate 1 rather than poles to ensure their permanency and deter elephants from crossing into crop gardens.

More beehives should be supplied to crop farmers in Rurama Parish, Ruteete sub-county. In Burunda village Rurama Parish, beehives were destroyed by chimpanzees, so there were no new 
beehives, supplied in Burunda parish and elephants crossed freely into farmers' gardens. There are no beehive or beehive fences in Kasojo village, Kanyawara Parish in Kiko trading center. Farmers continue to guard crop gardens from crop-damaging wildlife especially chimpanzees. In some areas, where there are no beehives as an intervention, some farmers skip crop growing seasons or rent land in other villages where there is no crop-damaging wildlife. Hiring an acre of land is about 300,000Uganda shillings per season. Where there are no beehives, it was established that elephants cross and trample on onions especially in Ibuga Parish. Beehive fences had just been supplied to Nyabuharwa parish and the fences had not yet been set up.

The study discovered that the decision of where to put the beehives/fences depended on the problem animal report data which indicated hot spot areas, community calls for intervention, and also the availability of funds. Funding for beehives fences is allocated from the revenue sharing scheme/ funds of the Uganda Wildlife Authority. The effect of beehive fences in deterring cropdamaging wildlife is associated with beehives short-term low-cost control and multiple benefits, such as protecting crop gardens and providing honey at the same time (Ciska et al., 2018).

Studies by Ciska et al., (2018) also reveal the effectiveness of setting up beehive fences around the boundary of Udzungwa National Park in Tanzania to control elephant damage on crops. Ciska et al., (2018) tested the efficacy of beehive fences on the protection of community gardens adjacent to the Udzungwa Mountains National Park over one year. A beehive fence was introduced and subsequently extended along the park boundary. The probability that one or more farms experienced crop loss from elephants on a given day was reduced in the presence of the fence and was reduced further as the fence was extended. This study suggests that expanding the beehive fence network limits the crossing of elephants into crop gardens to damage crops. Around Kibale National Park farmers reported that elephants could still cross at points where there were no beehive fences. Expanding beehive fence lines is crucial in addressing wildlife crop damage.

\section{Planting Mauritius thorn fences as an intervention to deter crop damaging wild animals}

Mauritius thorns are planted alongside either trench or as a separate intervention at the boundary of the park. Mauritius thorns hedges aim to deter primates from crossing park boundaries and damaging crops. However, neglecting to maintain Mauritius thorns reduces their efficacy to deter crop-damaging wildlife species. Due to a non-maintained Mauritius thorn hedge, farmers in Kyakabuzi village, Rurama parish in Kabarole district complained that monkeys and baboons could easily move through Mauritius thorn hedge. From observation, Mauritius thorn hedges which were planted and well maintained along the trenches helped to hold soils firmly. Planting of Mauritius thorn hedges along trenches helped to stop elephants from backfilling the trenches with soil. In instances where animals stray from the park into crop farms, KNP law enforcement team scare-shoot in the air using firearms to chase stray animals back into the park to protect crop farms from damage by wildlife (UWA, 2017).

"Uganda Wildlife Authority is no longer maintaining the Mauritius thorn hedges. The plants have colonized our land. I uprooted most of the Mauritius thorn hedges/fences after realizing 
Vol. 06, No. 04; 2021

ISSN: $2456-8643$

that it is an aggressive plant species" respondent from Rwetera village, Ruteete S/C, Kabarole district.

\section{Trenches (ET) as crop protection interventions against wildlife}

The process of digging trenches starts with the Uganda Wildlife Authority (UWA) represented by the park management team negotiating with the maintenance workers who are always members of the community where the trench is to be dug to come up with the task fee for each meter an individual is to dig or maintain, Mutonyi pers. comm 2020. The protected area management which is Kibale National Park enters into a Memorandum of Understanding (MoU) with members of the community who are to dig or maintain the trench. A foreman is selected amongst the members of the community and UWA agrees on how much and how often workers are to be paid. After this process, digging of the trench commences. The foreman compiles the number of meters dug or maintained by each worker and presents it to the Warden Community Conservation at the agreed day of payment. These records are verified and payments are made.

Some tea companies are against digging trenches. For instance, in Kiko trading center, Kiko tea estate did not support digging of the trench. Kiko tea estate refused UWA to dig a trench around Kasojo Cell in Kiko trading center. In such instances, UWA can provide beehives and set up beehive fences at the boundary with Kiko Tea estate to stop elephants from crossing to crop farmers' gardens.

In Kahangi parish, Hakibaale sub-county in Kabarole district, trenches were not dug on the side of the tea company. Elephants easily cross on that side to damage crops. In Burunda village, Rurama Parish, Ruteete sub-county, Mukwano Group of the company owns a vast piece of land that is not developed yet. There are neither trenches nor beehives. There are no trenches in Rwetera and Burunda villages in Rurama parish, Ruteete sub-county.

Observations made show that elephants continue to cross at some points where it's a bit boggy. In rocky areas such as Kakooga Parish in Rwimi sub-county, trenches were not completed. In Rurama parish, elephants continue to cross with ease at points where there are no trenches. There is an urgent need to complete trenches in Rurama parish and supply more beehives in Kakooga parish where trenches are not completed.

In Rurama parish, the $5.7 \mathrm{~km}$ trench was not evenly dug. Ideally, the trench should be dug at $6 \mathrm{ft}$ deep and $5 \mathrm{ft}$ wide. For the case of Kyakabuzi trench in Rurama parish, about 2 kilometers of the trench were dug at 1.7 meters. This was observed and established at points where the soils were deemed rocky. The rocky nature of soils also affected the effectiveness of trenches since elephants could easily cross at shallow points. At such shallow points, farmers reported the loss of some crops such as flac seeds to elephants. A kilogram of flac seeds cost 40,000 Uganda shillings

Where trenches are dug by the KNP management and eucalyptus trees are planted as boundary markers such as in Hakibaale sub-county, eucalyptus trees were reported and observed to firmly hold the soil together when it had fully established. In this area, farmers reported that trenches 
could not easily be filled back with soil. Trenches were reported as an effective intervention in stopping elephants from crossing into crop gardens to damage crops.

Though trenches were dug in response to problem data collected and complaints from communities. Some areas in sub-counties such as Busoro still had no trenches, despite the subcounty being listed among those highly afflicted through crop damage by wildlife. Elephants still crossed into crop farms at such points where trenches were not dug. Further still where River Kyawankada stopped, elephants could easily cross damage maize gardens.

During the process of revenue sharing, farmers in parishes bordering the national park are allowed to select projects which they feel are more appropriate as an intervention to problem animal management. In Kahangi Parish, Nyakabingo village the only village that borders the park in Hakibaale sub-county, farmers preferred a trench dug as a deterrent to wild animals that that damage their crops as opposed to other interventions such as setting up beehive fences

The trench network in Kasenda sub-county covers two villages of Mukole and Kanyante. The trenches were well maintained with elephant grass planted along the banks to stop elephants from backfilling the soil. Elephants were reported to pour back soil excavated from trenches so that they can easily cross to devour crops. Farmers who participated in maintaining the trench revealed that their motivation to do so was to stop elephants from damaging their gardens.

The trench in the Kakooga sub-county was dug in March 2021 mainly to protect maize farms of Rwimi prison from damage by elephants. From observations made at a trench in Kakooga, the trench is separated by a public road to Kamwenge Town. Elephants were reported to cross at this point where the trench was not dug. Setting up an elephant deterrent board at this point is expected to stop elephants from crossing to crop farms.

In Kasese District, the trench is found in Ibuga village, Hiima Parish, Kitswamba sub-county. The trench was dug around Ibuga prison farm where crops are grown. The trench mainly protects maize and watermelon gardens from damage by elephants. Despite the trench dug, Ibuga Farm Prison employs shamba guards to protect farms since, during the rainy season, the trench is easily filled up with soil enabling elephants to cross into crop farms. Ibuga trench was dug in 2019 to stop elephants and hippopotamuses from damaging maize, watermelon, pineapples, and bananas, the major crops grown by Ibuga Prison. Hippopotamuses reported damaging the mentioned crops from the nearby River Nsongi.

Whereas the community is paid to maintain the trench in Kinyantale Parish, the trench was not maintained. Non-maintenance of the trench network was associated with the fact that the trench was not bordering any crop farms. The trench in Kinyantale Parish borders Kinyantale tea plantation which is owned by Rwenzori Commodities Limited. Tea is popularly grown as a commercial buffer crop in Kabarole and Kyenjojo districts (see Plate 3).

Physically chasing animals from crop gardens

Locally chasing animals from gardens is laborious, time-consuming, and poses risks of crop farmers being hurt by crop-damaging species such as elephants. Protected area conservation priorities for KNP could focus on digging more trenches to deter elephants from crossing into 
farmers' gardens. These trenches should be routinely maintained to ensure their efficiency. Farmers believe that the most effective and safest means of crop guarding against all kinds of animals were farmers gathering in big numbers to make noise, erect watchtowers to observe and chase baboons and primates from entering gardens (Nyirenda et al., 2013; Sudip and Siddhartha, 2015). In this study by Sudip and Siddhartha (2015), it was discovered that though crop guarding was intensive, it was not found to be able to prevent crop damage completely, more studies are recommended to develop site-specific studies for crop damage management by wildlife.

Physical guarding was perceived as being the most effective method; though there are reports of damage resurgence by bush pigs when farmers were absent to guard their crops. Hill (2017), regarded guarding as a method to control wildlife damage as one which requires constant human presence, as tedious and time-consuming. Tweheyo et al., (2012), also noted that guarding as a method pre-disposes farmers to injury and possible spread of zoonotic diseases. Tweheyo et al., (2017) study evaluated the community control methods to promote biodiversity conservation and farm production.

\section{Lighting fire to chase elephants}

Lighting fires to chase elephants and to scare them from entering crop gardens requires constant human presence, it requires a lot of labour and fuel-wood to keep the fire burning all night. It is a good complementary technique, but supplying such farmers with more beehives to set beehive fences or empowering them with alternative livelihood projects such as piggery or goat farming is a better idea to mitigate crop damage.

\section{Drumming to chase problem animals from gardens}

Although some crop farmers sound drums, jerry cans, and empty tins to chase away elephants and other crop-damaging species such as primates from their gardens, it was reported that elephants had gotten used to sounds from the common instruments used by crop farmers. Elephants could no longer respond to the sounds until UWA staff were called to scare shoot animals back to the park.

\section{CONCLUSION AND RECOMMENDATIONS}

Digging trenches, planting Mauritius thorn hedges, and setting up beehive fences are considered the most effective crop protection interventions for the management of wildlife crop damage Kibale National Park (KNP). Digging trenches, setting up beehive fences, and planting Mauritius thorn hedges as interventions are initiated by Uganda Wildlife Authority - the institution mandated to manage Kibale and other national parks in Uganda. Funds that are invested in these interventions are generated through gate collection fees $20 \%$ of which is allocated to communities in parishes bordering KNP as a revenue-sharing scheme. A payment of Ugandan shillings approximated from 5,000 to 15,000 is paid to either excavate or maintain trenches. A trench network of about $84 \mathrm{~km}$ was dug around KNP. Farmers construct shelters where they stay while guarding crops. Some farmers chase wild animals by throwing stones, lighting fires at night to scare away elephants from their gardens while others sound drums, empty jerry cans, and empty tins to chase away wild animals from gardens.

It is recommended that Kibale National Park management should expand the trench network around the park, maintain Mauritius thorn hedges, increase funds shared from revenue sharing 
Vol. 06, No. 04; 2021

ISSN: $2456-8643$

scheme aimed at maintaining the existing trench network. The park management is further urged to distribute more beehives to expand the beehive fence line.

Acknowledgement

The authors appreciate the efforts of the community conservation and development warden at Kibale National Park - Rose Mutonyi and community conservation and development rangers Ricky Tusiime, Assimwe Robert, Mutabazi Anna, Sentume Chris Nyanzi and Bagonza Allan for diligently participating in the process of data collection.

Conflict of interest:

The authors express no conflict of interest.

\section{REFERENCES}

Akampulira E, Bitariho R, and Mugerwa B (2015). An assessment of the effectiveness of Nkuringo Buffer Zone in Mitigating Crop Raiding Incidences around Bwindi Impenetrable National Park, S.W. Uganda. A technical report for the International Gorilla Conservation Programme. PP 38.

Birungi P. (2021). Kabarole District Uganda - Population, Statistics, Charts, Map and Location. Retrieved from www.citypopulation.de: https://www.citypopulation.de/en/uganda/western/admin/010_kabarole

Ciska PJ, Scheijen SA, Smith J, Trevor J, and Katarzyna N (2016). Efficacy of beehive fences as barriers to African elephants: a case study in Tanzania. Oryx, 2019, 53(1), 92-99 (C) 2018 Fauna \& Flora International DOI: 10.1017/S0030605317001727.

Hill C.M (2017). Primate Crop Feeding Behaviour, Crop Protection, and Conservation: International Journal of Primatology 38:385-400.

Mackenzie CA and Ahabyona P (2011). Elephants in the garden: Financial and social costs of crop-raiding. Ecological Economics 75:72-82.

Mackenzie CA, Raja R, Ridhwana K (2015). Chasing baboons or attending class: protected areas and childhood education in Uganda. Environmental Conservation 42: 373-383. Cambridge University Press.

Mollel T. (2017). Assessment of Human-Wildlife Conflicts in Wildlife Management Areas: A Case of Burunge WMA. The Open University of Tanzania., 57-58.

Naughton-Treves $\mathbf{L}$ and $\mathbf{L}$ 'Roe $\mathbf{J}$ (2017). Forest edges in western Uganda: From refuge for the poor to zone of investment. Forest Policy and Economics 84, 102-111.

Nyirenda VR, Willem JM, Brian KR, Andrew IP, Harry NC (2013). Wildlife-crop damage valuation and conservation: conflicting perception by local farmers in Luangwa Valley, eastern Zambia. International Journal of Biodiversity Conservation, 5:741-750.

Osei-Owusu Y. (2018). Human-Wildlife Conflict: Elephants-Technical Manual. Conservation Alliance, 241-259.

Rebekah, K. (2015). An assessment of perceived crop damage in a Tanzanian village impacted by human-elephant conflict and an investigation of deterrent properties of African elephant (Loxodonta africana) exudates using bioassays: A Thesis Submitted to the Graduate Faculty of Georgia Southern University in Partial Fulfillment of the Requirements for the Degree-master of science. Statesboro, Georgia. 
Riju PN and Jayson EN (2016). Effectiveness of Beehive Fences to Deter Crop Raiding Elephants in Kerala, India. International Research Journal of Natural and Applied Sciences Vol. 3, Issue 1, Jan 2016. IF- 2.818, ISSN: (2349-4077)

Rod P, William DG (2016). Integrated Wild Pig Control ${ }^{\mathrm{TM}}$ Results from the EPD Pennahatchee Creek Project. Proceedings of the $16^{\text {th }}$ Wildlife Damage Management Conference. Pp. 3-4. Tennessee, USA.

Rusoke T, Mbahinzireki G, Orach-Meza F (2020). Philosophical perspectives on wildlife crop damage and management. Dir. Res. J. Agric. and Food Sci. 8. p.177-184. ISSN 2354-4147: DOI 10.26765/DRJAFS596018732. https://directresearchpublisher.org/drjafs/abstract/philosophicalperspectives-on-wildlife-crop-damage-and-management.

Rusoke, T (2021). Agriculture and proximity to protected areas: What's the future for people and wildlife? https://www.newvision.co.ug/articledetails/109105

Shova T (2015). Effectiveness of crop protection methods against wildlife damage: A case of two villages at Bardia National Park, Nepal. Crop Protection 29:1297-1304.

Sudip P and Siddhartha BB (2015). Crop protection and Its Effectiveness against Wildlife: A case study of Two Villages of Shivpuri National Park, Nepal. Nepal Journal of Science and Technology 16:1-10.

Tweheyo M, Mwesigye DT, Turyahabwe N, Asiimwe A, Orikiriza L (2012). Wildlife damage and control methods around Lake Mburo National Park, Uganda. International Journal of Pest Management, 58:25-31.

Uganda Wildlife Authority (2015). Kibale National Park: Management Plan 2015-2024. Uganda Wildlife Authority, Kampala, Uganda.

Uganda Wildlife Authority (2017). About Kibale National Park, Tariff Guide 2017-2018. Uganda Wildlife Authority, Kiira Road Kampala, Darwin Publishing Unit. 